\title{
Factors Motivating the Farmers to Practice Collective Farming in Tirunelveli District, India
}

\author{
V. Jothika ${ }^{1^{*}}$, R. Rajasekaran ${ }^{2}$, C. Karthikeyan ${ }^{3}$ and R. Gangai Selvi ${ }^{4}$ \\ Department of Social Sciences, Agricultural College and Research Institute, \\ Killikulam -628252, India \\ *Corresponding author
}

\begin{tabular}{|l|}
\hline Ke y w o r d s \\
$\begin{array}{l}\text { Collective farming, } \\
\text { Corpus fund, } \\
\text { Motivational factor }\end{array}$ \\
\hline Article Info \\
\hline $\begin{array}{l}\text { Accepted: } \\
15 \text { April } 2020 \\
\text { Available Online: } \\
10 \text { May } 2020\end{array}$ \\
\hline \hline
\end{tabular}

A B S T R A C T

Collective farming is a practice of agriculture where the farmers join hands with one another and become a joint enterprise. In Tamil Nadu, the scheme was brought to empower the lives of small and marginal farmers. This paper deals with the motivational factors responsible for the practice of collective farming. The study was carried out in the Alangulam block of Tirunelveli District of Tamil Nadu. A sample size of 120 farmers who were practicing collective farming was taken for the study. The data were collected by using a well-structured and pre-tested interview schedule. The recorded data were analyzed and the results were interpreted. The factors such as the corpus fund provided to the group (94.20\%), the increase in income and livelihood of the farmers engaged in collective farming $(86.70 \%)$, purchase of machinery according to the requirements of the group members $(76.70 \%)$, leasing of machineries among the groups (70.80\%), shares given to the members (69.20\%), use of lease amount for input procurement for the group members $(58.30 \%)$, regular trainings to the members $(55.00 \%)$, maintenance of record of the activities carried out in group $(51.70 \%)$ motivated to a higher extent.

\section{Introduction}

Indian agriculture is a key contributor to India's growth and continues to be one of biggest employer. The sector is likely to grow at an approximate rate of $2 \%$ per annum. To attain this, the sector needs to adapt to the various challenges such as climate change, lack of labour, marketing of the produce, etc. Collective Farming was one such initiative to overcome the struggles faced by the small and the marginal farmers.

Collective farming is one of the types of agricultural production where the land of the Small and Marginal farmers are pooled 
together and the farming activities are done in a collective manner. In Tamil Nadu $92 \%$ of operational holdings belong to small and marginal farmers who have limited capacity to mobilize credit, adopt latest technologies and value addition to their agricultural produce. The Government of Tamil Nadu has announced this innovative programme (201718) for organizing small and marginal farmers into "Farmer Producer Groups (FPG)" which will be federated into "Farmer Producer Organizations (FPO)" to promote collective farming for credit mobilization, better adoption of technology and facilitate effective forward and backward linkages. The starting point of this collective farming is the formation of Farmer's Interest Group (FIG) which consists of 20 range farmers followed by the formation of Farmer's Producer Group (FPG) which consists of 5 Farmer's Interest Group and later Farmers Producers Organisation federates 10 FPGs each which are registered under the Companies Act, 2013.

Christian Felzensztein and Eli Gimmon (2007) stated that the culture influenced the small firms in Scotland in building inter firm cooperation for international marketing activities.

Giuseppinna Migliore et al., (2014) studied how the farmer's attitude influence their decision to participate in some form of civic agriculture and said that personal relations and a greater presence of community relations fosters a greater role in farmer's decision of participation.

This study was carried out to know the various components which motivated the farmers to practice collective farming, therefore the small and marginal farmers could be motivated to a higher extent and more number of farmers can be made to practice collective farming.

\section{Materials and Methods}

Ex-post facto research design was used in this study by considering the objective and type of information needed. The present study was conducted in Tiruneveli district as it is a predominent agriculture district of Tamil Nadu. The district comprised of nineteen blocks. Alangulam block was selected purposively for the study, four villages from Alangulam block such as Vadiyoor, Melamaruthappapuram, Ayyanarkulam and Sivalarkulam were identified by considering their performance in the collective farming activity during previous year. About 30 farmers per village were selected randomly. Hence a total number of 120 farmers were selected randomly for the study. The data were collected by using a well-structured and pre-tested interview schedule. The analysis was carried out by applying suitable statistical tools such as percentage analysis, cumulative frequency and factor analysis. This approach involves finding a way of condensing the information contained in a number of original variables into a smaller set of dimensions (factors) with a minimum loss of information (Hair et al., 1998).

\section{Results and Discussion}

The motivational factors that influenced the farmers to practice Collective Farming were identified and prepared with the help of project personnel. The data regarding the motivational factors were analyzed using percentage analysis and the results are presented in the Table 1.

From Table 1, it could be inferred that 94.20 per cent of the respondents were motivated due to the corpus fund provided to the group followed by the factors such as increase in income and livelihood (86.70\%), purchase of machinery according to the requirements of the group members $(76.70 \%)$, leasing of 
machineries among the groups (70.80\%), shares given to the members $(69.20 \%)$, use of lease amount for input procurement for the group members $(58.30 \%)$, regular trainings to the members $(55.00 \%)$, maintenance of record of the activities carried out in group (51.70\%) as these factors benefited them to a greater extent and the least per cent of 1.70 per cent was obtained on collective decision on any issues arising in the group.

From the table 2, it could depicts the following inferences such as the constituting variables of each factor:

First Factor: Based on the factor loading the two constituting variables of the first factor included provision of corpus fund to the group (X1) and purchase of machinery (X17). According to the constituting variables the first factor was named as Credit factor. From the Eigen value of this factor (2.211) Credit factor was the most important influencing factor on the Collective Farming Scheme.

Second Factor: Three constituting variables present in the second factor were FPG can join with other FPG (X20), record maintenance (X13), Collective input purchase to the group members (X4) (negatively influencing). According to the nature of these variables the second factor was named as Activities of the group. The variance per cent was 9.137.

Third Factor: Two variables constituting the third factor were combining various resources (X11) and priorities to other government schemes (X3) and this factor was named as Consolidation and Consideration. The variance per cent was 7.80 .

Fourth Factor: There are two variables present in this factor. They were shares given to the members (X12) and leasing of machinery (X18). According to the variables present the factor was named as Priority and the variance per cent observed was 7.001.

Fifth Factor: This factor includes the following variables, selection of office bearers (X16) and Drawing virtual boundaries in the farm (X10). The factor was named as Social participation according to the variables and the variance per cent was found 6.770.

Sixth Factor: The variable constituting this factor included group marketing (X6) and was named as Market factor. The variance per cent of this factor identified 5.903.

Seventh Factor: The constituting variable of the seventh factor was Farming practices done collectively (X9) and the variance per cent obtained was 5.777 .

Eighth Factor: Regular trainings conducted in the group (X14) was the constituting variable and the factor named as Knowledge gain factor, the variance percent observed as 5.269.

Ninth Factor: This factor consists of the variable increase in livelihood and was named as Socio Economic factor in which the variance per cent was 5.041.

Out of 20 variables 15 have been grouped into 9 factors. The five variables namely the consolidation of land holdings (X5), information gaining and sharing (X7), collective decision on any group (X8), contact with large number of people (X15) and use of lease amount (X19) have not been grouped under any factor and it can also be said that these five variables were not important and may not be considered for future studies. 
Table.1 Factors that motivates the farmers to practice collective farming $(n=120)$

\begin{tabular}{|c|c|c|c|}
\hline $\begin{array}{c}\text { S. } \\
\text { No. }\end{array}$ & Motivational factors & No. & $\begin{array}{l}\text { Per } \\
\text { cent }\end{array}$ \\
\hline 1 & Provision of corpus fund to the FPG & 113 & 94.20 \\
\hline 2 & Increase in income and livelihood of the members of the group & 104 & 86.70 \\
\hline 3 & Member of FIG given priority for other government schemes & 12 & 10.00 \\
\hline 4 & Collective purchase of inputs for the members of the group & 21 & 17.50 \\
\hline 5 & Consolidation of land holdings of the group members & 16 & 13.30 \\
\hline 6 & Group marketing of the produce of the members of the group & 18 & 15.00 \\
\hline 7 & Information gaining and sharing among the group members & 13 & 10.80 \\
\hline 8 & Collective decision on any issues arising in the group & 2 & 1.70 \\
\hline 9 & Farming practices done collectively & 6 & 5.00 \\
\hline 10 & Drawing Virtual boundaries to pool the land of the members & 8 & 6.70 \\
\hline 11 & $\begin{array}{l}\text { Combining various resources like cattle, machinery and other } \\
\text { entities possessed by the group members }\end{array}$ & 22 & 18.30 \\
\hline 12 & Shares given to the members & 83 & 69.20 \\
\hline 13 & Maintenance of record of the activities carried out in group & 62 & 51.70 \\
\hline 14 & Regular trainings to the members & 66 & 55.00 \\
\hline 15 & Having contact with large number of people & 16 & 13.30 \\
\hline 16 & Selection of office bearers for the group & 7 & 5.80 \\
\hline 17 & $\begin{array}{l}\text { Purchase of machinery according to the requirements of the group } \\
\text { members }\end{array}$ & 92 & 76.70 \\
\hline 18 & Leasing of machineries among the groups & 85 & 70.80 \\
\hline 19 & Use of lease amount for input procurement for the group members & 70 & 58.30 \\
\hline 20 & FPG can join with other FPG and share their activities & 18 & 15.00 \\
\hline
\end{tabular}


Table.2 Extracted factors with Eigen value after rotation

\begin{tabular}{|c|c|c|c|c|}
\hline $\begin{array}{l}\text { S. } \\
\text { No. }\end{array}$ & Factors (Eigen value) & Variables under Factors & $\begin{array}{c}\text { Factor } \\
\text { loadings }\end{array}$ & $\begin{array}{c}\text { Variance } \\
(\%)\end{array}$ \\
\hline \multirow[t]{2}{*}{1} & \multirow[t]{2}{*}{ Factor $1(2.211)$} & $\begin{array}{l}\text { Provision of corpus fund to the } \\
\text { group }\end{array}$ & 0.874 & \multirow[t]{2}{*}{11.054} \\
\hline & & Purchase of machinery & 0.842 & \\
\hline \multirow[t]{3}{*}{2} & \multirow[t]{3}{*}{ Factor $2(1.827)$} & FPG can join with other FPG & 0.688 & \multirow[t]{3}{*}{9.137} \\
\hline & & Record maintenance & 0.618 & \\
\hline & & $\begin{array}{l}\text { Collective input purchase to the } \\
\text { group members }\end{array}$ & -0.515 & \\
\hline \multirow[t]{2}{*}{3} & \multirow[t]{2}{*}{ Factor $3(1.560)$} & Combining various resources & 0.782 & \multirow[t]{2}{*}{7.801} \\
\hline & & $\begin{array}{l}\text { Priorities to other government } \\
\text { schemes }\end{array}$ & 0.598 & \\
\hline \multirow[t]{2}{*}{4} & \multirow[t]{2}{*}{ Factor 4 (1.402) } & Shares given to the members & 0.713 & \multirow[t]{2}{*}{7.001} \\
\hline & & Leasing of machinery & 0.608 & \\
\hline \multirow[t]{2}{*}{5} & \multirow[t]{2}{*}{ Factor 5 (1.354) } & Selection of office bearers & 0.729 & \multirow[t]{2}{*}{6.770} \\
\hline & & $\begin{array}{l}\text { Drawing virtual boundaries in the } \\
\text { farm }\end{array}$ & 0.659 & \\
\hline 6 & Factor $6(1.181)$ & Group marketing & 0.783 & 5.903 \\
\hline 7 & Factor 7 (1.155) & Farming practices done collectively & 0.847 & 5.777 \\
\hline 8 & Factor 8 (1.054) & $\begin{array}{l}\text { Regular trainings conducted in the } \\
\text { group }\end{array}$ & 0.821 & 5.269 \\
\hline 9 & Factor $9(1.008)$ & Increase in livelihood & 0.655 & 5.041 \\
\hline
\end{tabular}

Table.3 Extent of motivation of the farmers involved in Collective Farming ( $\mathrm{n}=120)$

\begin{tabular}{|c|l|c|c|}
\hline S. No. & Motivation & Numbers & Percentage \\
\hline $\mathbf{1 .}$ & Low & 53 & 44.20 \\
\hline $\mathbf{2 .}$ & Medium & 51 & 42.50 \\
\hline 3. & High & 16 & 13.30 \\
\hline
\end{tabular}


The various components of Collective Farming which motivated the farmers to participate in the Collective Farming Scheme was observed low (44.20\%) and this was due to their minimum awareness regarding the components. 42.50 per cent opined that the components have motivated up to medium level and followed by high (13.30\%) which probably included the corpus fund and the machinery (Table 3).

In conclusion, collective Farming scheme has been brought to improve the farming practices of the small and marginal farmers as well as to improve their standard of living. In this study, though there were more number of motivational factors the overall motivation level of the farmers were found low which was due to lack of awareness regarding the presence of those factors. Few factors namely the corpus fund provided to the group, the increase in the livelihood pattern of the farmers and the machineries motivated the respondents to a higher extent as they were necessary for the farmers to build their agricultural pattern. Higher the motivation of the farmers, higher their interest in the group activities and therefore these components can be made to be known to a larger extent of farmers by conducting meetings stating the presence of various components of Collective Farming as well as their benefits to all the members of the Farmers Interest Group as well as the Farmers Producer Group and also the farmers who are not involved in group farming.

\section{References}

Hair, J.F. Jr., Anderson, R.E., Tatham, R.L. and Black, W.C. 1998. Multivariate Data Analysis, (5th Edition). Upper Saddle River, NJ: Prentice Hall, pp. 91-146.

Felzensztein, C. and Gimmon, E. (2007), "The influence of culture and size upon inter- firm marketing cooperation: A case study of the salmon farming industry", Marketing Intelligence \& Planning, Vol. 25 No. 4, pp. 377-393.

Migliore, G. Caracciolo, F., A., G. and Cembalo, L. (2014), "Farmers' Participation in Civic Agriculture: The Effect of Social Embeddedness, The Journal of Culture and Agriculture, Vol. 36 No. 2, pp. 105-117.

https://www.pwc.in/government-reforms-andinfrastructuredevelopment/agriculture/top-fivetrends-indian-agriculture-is-expectedto-witness-in-2019.html http://sfacindia.com/List-of-FPOStatewise.aspx

\section{How to cite this article:}

Jothika, V., R. Rajasekaran, C. Karthikeyan and Gangai Selvi, R. 2020. Factors Motivating the Farmers to Practice Collective Farming in Tirunelveli District, India. Int.J.Curr.Microbiol.App.Sci. 9(05): 1901-1906. doi: https://doi.org/10.20546/ijcmas.2020.905.216 